\title{
Teologia e Literatura Fantástica: A redenção na Trilogia Cósmica de C. S. Lewis
}

\author{
Orientador: Joel Portella Amado \\ Mestrando: Marcio Simao de Vasconcellos \\ Área de Concentração: Teologia Sistemático-Pastoral
}

Linha de Pesquisa: Religião e Modernidade

Teologia e Literatura Fantástica: a redenção na Trilogia Cósmica de C. S. Lewis investiga a relação entre teologia e literatura, destacando a importância de se ultrapassar o racionalismo reducionista, seja na prática teológica, seja na vida cotidiana. Além disso, desenvolve o conceito de redenção cristã analisando a maneira como este tema é apresentado na literatura fantástica, especialmente a forma que ele é retratado na Trilogia Cósmica do escritor irlandês C. S. Lewis. A partir desses pontos, propõe-se a literatura fantástica como espaço potencial para a prática teológica.

Palavras-chave: Redenção; Literatura Fantástica; C. S. Lewis. 